\title{
Top Down Characterization of Secreted Proteins from Mycobacterium tuberculosis by Electron Capture Dissociation Mass Spectrometry
}

\author{
Ying Ge, Mariam ElNaggar, Siu Kwan Sze, Han Bin Oh,* \\ Tadhg P. Begley, and Fred W. McLafferty \\ Department of Chemistry and Chemical Biology, Baker Laboratory, Cornell University, Ithaca, NY, USA
}

Helena Boshoff and Clifton E. Barry, III

Tuberculosis Research Section, NICID, NIH, Rockville, MD, USA

\begin{abstract}
Secreted proteins of Mycobacterium tuberculosis are implicated in its disease pathogenesis and so are considered as potential diagnostic and vaccine candidates. The search for these has been slow, even though the entire genome sequence of $M$. tuberculosis is now available; of the 620 protein spots resolved by 2-D gel electrophoresis, 114 secreted proteins have been identified, but for only 13 has the primary structure been partly characterized. For comparison, in this top down mass spectrometry (MS) approach the secreted proteins were precipitated from cell culture filtrate, resuspended, and examined directly by electrospray ionization (ESI) Fourier transform MS. The ESI spectra of three precipitates showed 93, 535, and 369 molecular weight $\left(\mathrm{M}_{\mathrm{r}}\right)$ values, for a total of 689 different values. However, only $\sim 10 \%$ of these values matched $( \pm 1 \mathrm{Da})$ the DNA predicted $\mathrm{M}_{\mathrm{r}}$ values, but these identifications were unreliable. Of nine molecular ions characterized by MS/MS, only one protein match was confirmed, and its isotopic molecular ions were overlapped by those of another protein. MS/MS identified a total of ten proteins by sequence tag search, of which three were unidentified previously. The low success of $\mathrm{M}_{\mathrm{r}}$ matching was due to unusually extensive posttranslational modifications, including loss of a signal sequence, loss of the $\mathrm{N}$-terminal residue, proteolytic degradation, oxidation, and glycosylation. Although in eubacteria the latter is relatively rare, a $9 \mathrm{kDa}$ protein showed 7 hexose attachments and two $20 \mathrm{kDa}$ proteins each had 20 attachments. For MS/MS, electron capture dissociation was especially effective. (J Am Soc Mass Spectrom 2003, 14, 253-261) @ 2003 American Society for Mass Spectrometry
\end{abstract}

$\mathrm{M}$ ycobacterium tuberculosis is an important human pathogen causing the chronic infectious disease tuberculosis that claims nearly three million lives annually [1-3]. Its secreted proteins are translocated across the cytoplasmic membrane, transported across the entire cell envelope, and subsequently localized in the extracellular milieu [4]. There is ample evidence that some of the secreted proteins of $M$. tuberculosis are essential to the pathogenesis of the disease and to its progress in the human host $[5,6]$. In addition to their immunostimulatory roles in directly interacting with the innate immune system [7], secreted mycobacterial proteins show great promise as potential

Published online February 24, 2003

Address reprint requests to Fred W. McLafferty, Department of Chemistry and Chemical Biology, Cornell University, Baker Laboratory, Ithaca, NY 14853-1301, USA.

* Current address: Department of Chemistry, Sogany University, Seoul 121-742, Korea. vaccine targets by virtue of their role as important T-cell antigens in the adaptive immune response [8-10].

The first two-dimensional (2-D) electrophoresis of culture supernatant proteins identified and partially characterized five major protein antigens [11], and this $\mathrm{N}$-terminal Edman sequencing and electrospray ionization (ESI) mass spectrometry (MS) identified 32 proteins from among 205 resolvable spots [12]. The elucidation of the entire genome sequence of $M$. tuberculosis $\mathrm{H} 37 \mathrm{Rv}$ (4.4 Mbp) in 1998 [13] allows prediction of the sequences for the expressed proteins, aiding in the conventional identification of 38 secreted proteins [14, 15]. In combination with mass spectrometry (MS), now a core instrumental technology for proteomics [16, 17], 49 secreted proteins have been identified out of 620 resolvable spots on 2-D gel electrophoresis by Rosenkrands et al. [18]. In total, 114 secreted proteins have been identified; however, for only 13 has the primary structure been partially characterized [11-15, 18-21].

The complexity of the secreted proteome of $M$. 
tuberculosis is indicated by the frequent loss of $\mathrm{N}$ terminal signal sequences during secretion $[4,9-12,15]$ and posttranslational modifications such as lipidation and glycosylation [20,21]. Although rarely observed in eubacteria, in immunology the glycosylated proteins may contribute to the interaction with the mammalian cells during infection [20,21].

This report utilizes the top-down MS/MS approach $[22,23]$ to identify proteins secreted into the extracellular milieu, in which mixed protein components are ionized and separated directly by Fourier transform MS and then dissociated MS/MS to provide fragment masses for matching against the DNA predicted sequence and for structural characterization of posttranslational modifications. This study also illustrates the applicability of the recently developed MS/MS technique of electron capture dissociation (ECD) [24-26]. As a nonergotic dissociation method, ECD provides far better localization of posttranslational modifications such as carboxylation [27], phosphorylation [28, 29], and glycosylation [30] that tend to be selectively lost in other methods that dissociate the weakest bonds.

\section{Experimental}

\section{Materials}

Concanavalin A (Con A) Sepharose was purchased from Amersham Pharmacia Biotech (Uppsala, Sweden) and the complete protease inhibitor cocktail tablets from Roche. All other chemicals were from Aldrich or Sigma and used without further purification.

\section{Preparation of Secreted Proteins from Mycobacterium tuberculosis}

M. tuberculosis H37Rv was diluted 1:100 from a logarithmic phase culture into GAS (per liter: $0.3 \mathrm{~g}$ of Bacto Casitone (Difco), $0.05 \mathrm{~g}$ of ferric ammonium citrate, $4.0 \mathrm{~g}$ of $\mathrm{KH}_{2} \mathrm{PO}_{4}, 2.0 \mathrm{~g}$ of citric acid, $1.0 \mathrm{~g}$ of L-alanine, $1.2 \mathrm{~g}$ of $\mathrm{MgCl}_{2} \cdot\left(\mathrm{H}_{2} \mathrm{O}\right)_{6}, 0.6 \mathrm{~g}$ of $\mathrm{K}_{2} \mathrm{SO}_{4}, 2.0 \mathrm{~g}$ of $\mathrm{NH}_{4} \mathrm{Cl}$, $1.80 \mathrm{ml}$ of $10 \mathrm{M} \mathrm{NaOH}$, and $10.0 \mathrm{ml}$ of glycerol) medium, grown for 1 or 3 weeks at $37^{\circ} \mathrm{C}$, and cells harvested by centrifugation [31]. The cell-free medium was sterilized by filtration through a $0.2 \mu \mathrm{m}$ filter; the proteins then precipitated by $80 \%$ acetone, or $15 \%$ trichloracetic acid (TCA). The sterile-filtered culture filtrate was concentrated approximately 10 -fold by ultrafiltration through a Pellicon XL filter (5 kDa exclusion limit) device (Millipore, Bedford, MA) before addition of $\left(\mathrm{NH}_{4}\right)_{2} \mathrm{SO}_{4}$ to $90 \%$ saturation. The acetone and TCA precipitates were redissolved in $6 \mathrm{M}$ urea or $8 \mathrm{M}$ guanidine $\cdot \mathrm{HCl}$ and the $\left(\mathrm{NH}_{4}\right)_{2} \mathrm{SO}_{4}$ precipitates were resuspended in $50 \mathrm{mM}$ Tris $(\mathrm{pH}=7.5,2 \mathrm{mM}$ DTT, 1 mM EDTA).
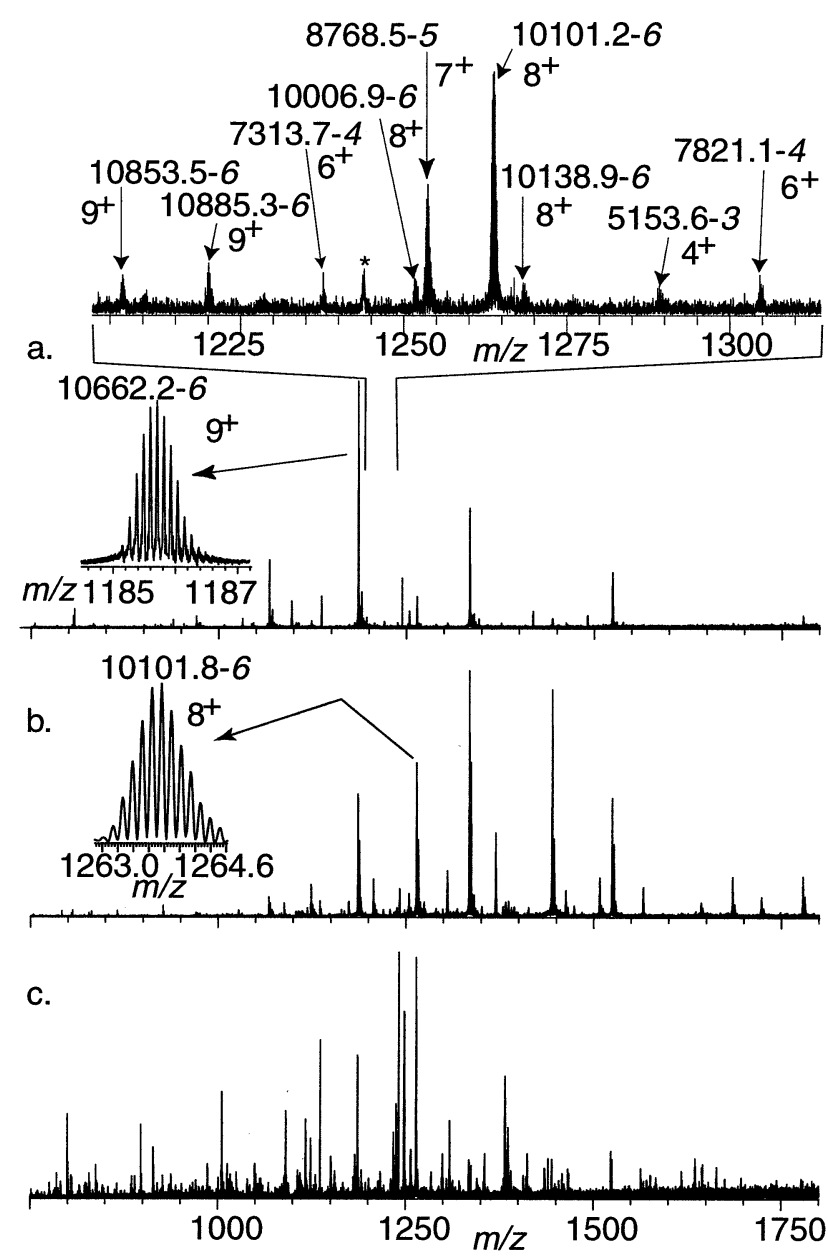

Figure 1. ESI/MS spectra of secreted proteins isolated from $M$. tuberculosis. (a) one-week cell growth, $80 \%$ acetone precipitation, redissolved in $6 \mathrm{M}$ urea (asterisk, noise peak); (b) three-week cell growth, 15\% TCA precipitation, redissolved in $6 \mathrm{M}$ urea; (c) three-week cell growth, $\left(\mathrm{NH}_{4}\right)_{2} \mathrm{SO}_{4}$ precipitation, redissolved in 50 $\mathrm{mM}$ Tris buffer.

\section{Glycoprotein Preparation}

After a three-week cell growth, PMSF (1 mM), EDTA (1 $\mathrm{mM}$ ) and the protease inhibitor cocktail were added to the culture filtrate, concentrated as described above and run through one or two Con A Sepharose column according to the procedures recommended by manufacturer. The enriched glycoproteins were then eluted with $0.5 \mathrm{M}$ methyl-glucopyranose. After being frozen in $-80^{\circ} \mathrm{C}$ and thawed, any precipitate was resuspended in $6 \mathrm{M}$ urea.

\section{MS Analysis}

The samples were desalted by ultrafiltration, Zip-Tip (Millipore, Bedford, MA) or reverse-phase peptide traps (Michrom Bioresources, Auburn, CA), washed with 2:96:2 (MeOH: $\left.\mathrm{H}_{2} \mathrm{O}: \mathrm{AcOH}\right)$, and step eluted with 50:48:2 ( $\mathrm{MeOH}: \mathrm{H}_{2} \mathrm{O}: \mathrm{AcOH}$ ) and 70:26:4 (MeOH: $\left.\mathrm{H}_{2} \mathrm{O}: \mathrm{AcOH}\right)$. Matrix-assisted laser desorption ionization data utilized a Voyager-DE-STR from Perseptive Biosystems Inc. 


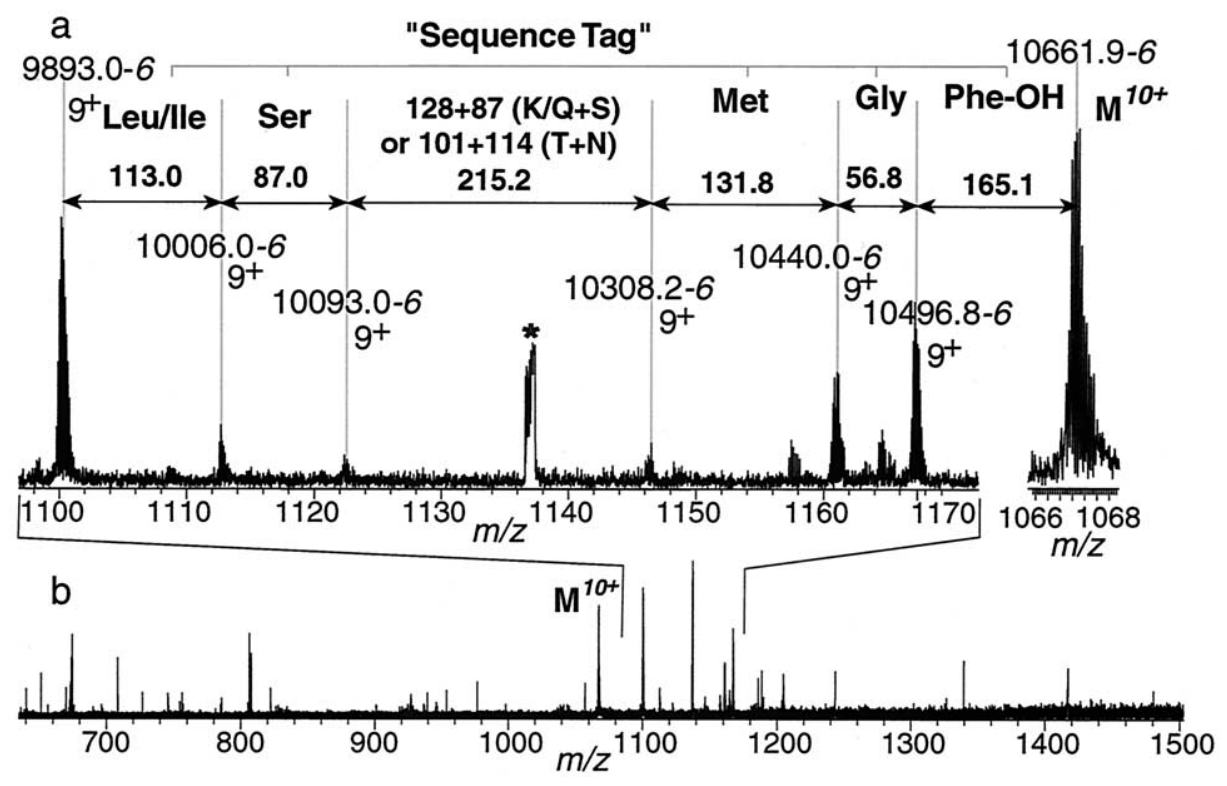

Figure 2. CAD spectrum of $10+10661.9$ Da ions from ESI of isolated proteins.

(Foster City, CA) ESI/MS and MS/MS data were acquired on a $6 \mathrm{~T}$ modified FTMS with nano-electrospray [22-26]. Specific ions were isolated using stored waveform inverse Fourier-transform [32], followed by sustained off-resonance irradiation collisionally-activated dissociation (CAD) [33, 34], infrared multiphoton dissociation (IRMPD) [35], and activated ion ECD [26]. Assignments of fragment masses and compositions used the computer program THRASH [36]. The mass difference (in units of $1.00235 \mathrm{Da}$, the weighted average of the isotopic mass differences for the average protein composition [36]) between the most abundant isotopic peak and the monoisotopic peak is denoted in italics after each reduced molecular weight $\left(\mathrm{M}_{\mathrm{r}}\right)$ value.

\section{Protein Identification by Data Base Searching}

The high-resolution molecular ion masses and the sequence tags were searched against the sequenced genome and ORF translations available on the Tuberculist Web Server for protein identification [37]. Monoisotopic protein masses were generated by the program PAWS [38]. The MS/MS fragments from CAD and IRMPD were used as input for the database retrieval algorithm DRA program provided by the laboratory of Neil Kelleher for searching against the protein database for protein identification [39].

\section{Results and Discussion}

Separation of Protein Mixture Subsets and Measurement of Component Molecular Weights

In the first step of the top-down approach, the secreted protein mixture is directly electrosprayed (ESI) into the mass spectrometer to produce an ESI spectrum of its components separated by the high resolving power of FTMS. After one-week of cell growth, the secreted proteins were precipitated from the culture filtrate using $80 \%$ aqueous acetone and resuspended into $6 \mathrm{M}$ urea. Despite difficulties with redissolving some portion of the precipitate, a single ESI analysis showed 131

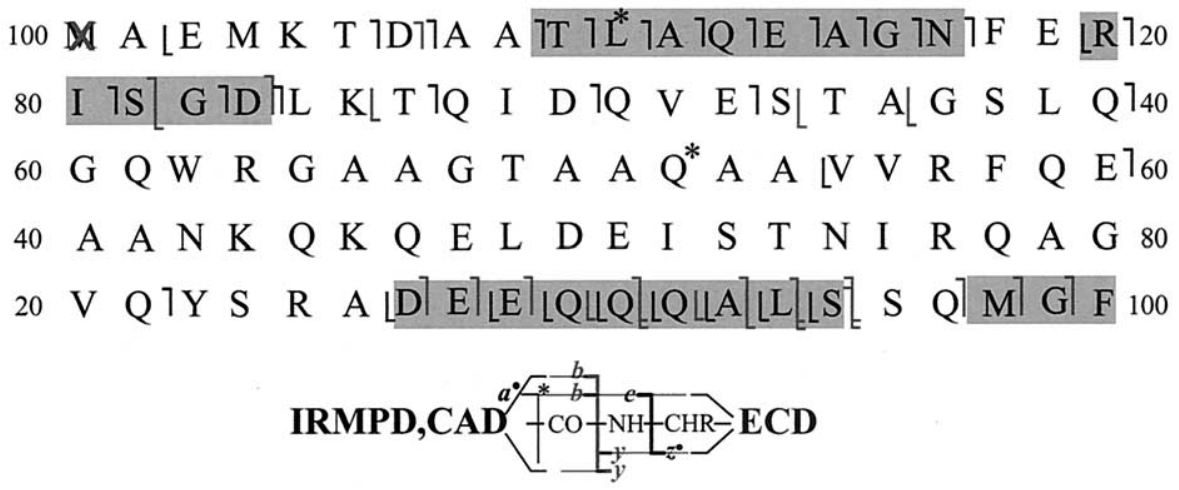

Figure 3. Sequence assignments from their MS/MS spectra for the $10662 \mathrm{Da}$ ions to CFP-10. 


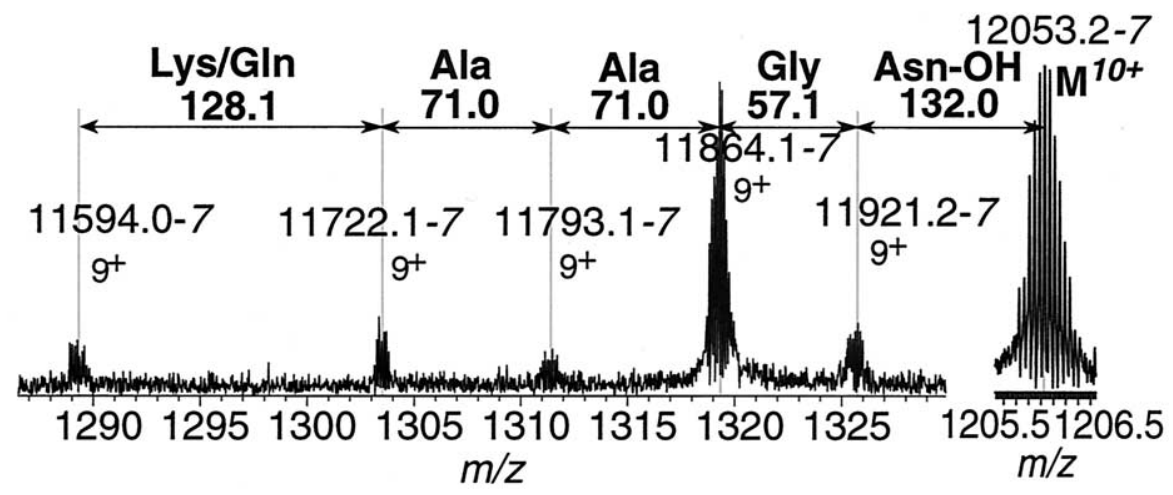

Figure 4. Partial CAD spectrum of the isolated 12053 Da ions.

isotopic clusters representing 88 different masses (the same $m$ value can be derived from several $m / z$ values) of 3-20 kDa (Figure 1a). While the spectrum was dominated by ions of $\mathrm{M}_{\mathrm{r}}=10662.2-6$, many other lower abundant proteins were also resolved (Figure 1a, top expansion). In contrast, the ESI spectrum of a $6 \mathrm{M}$ guanidine- $\mathrm{HCl}$ resuspended acetone precipitate gave 62 isotopic clusters representing 56 different masses (2-8 $\mathrm{kDa}$, spectrum not shown), of which five were not in the Figure 1a spectrum.

The duration of cell growth of M. tuberculosis was extended to three weeks without detecting cell lysis [31]; for the filtrate precipitated with $15 \%$ TCA and desalted, a single ESI spectrum revealed 226 isotopic clusters representing 139 different masses (Figure 1b). Using alternative different batches of cell growth, other desalting methods (ultrafiltration, reverse-phase protein/peptide trap), and different resuspension solu- tions, a total of 535 distinctive masses were observed in the eight ESI spectra, with the protein ions of $\mathrm{M}_{\mathrm{r}}=$ 10662 still the dominant species.

Upon concentrating the medium several fold by ultrafiltration, $\left(\mathrm{NH}_{4}\right)_{2} \mathrm{SO}_{4}$ precipitation, Tris buffer resuspension, and desalting, the ESI spectrum no longer had $\mathrm{M}_{\mathrm{r}}=10662$ as the predominant species, showing 272 isotopic clusters corresponding to 170 different masses (Figure 1c). Six additional ESI spectra of $\left(\mathrm{NH}_{4}\right)_{2} \mathrm{SO}_{4}$ precipitation but different desalting increased the overall total to 369 mass values of $3-25 \mathrm{kDa}$. In comparison, 2-D PAGE maps of the secreted proteins from $80 \%\left(\mathrm{NH}_{4}\right)_{2} \mathrm{SO}_{4}$ precipitation resolved 376 or 620 protein spots $[15,18]$.

These 369 molecular masses were compared to those of the 832 proteins predicted from the genome sequence. Surprisingly, only 47 could be matched within the $\pm 1 \mathrm{Da}$ error reasonable for the FTMS instrument

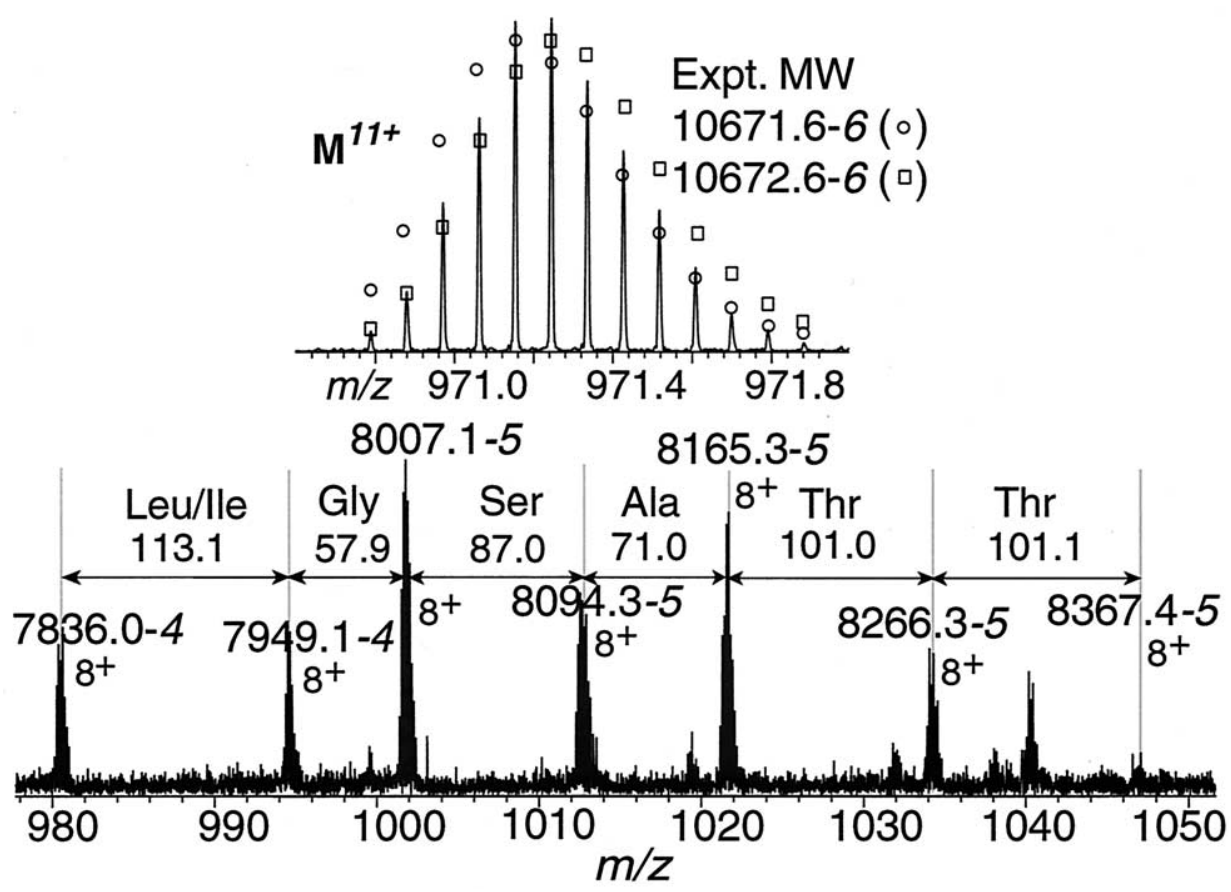

Figure 5. Theoretical isotopic distributions of the 10672/10673 isolated ions and (below) their partial CAD spectrum. 


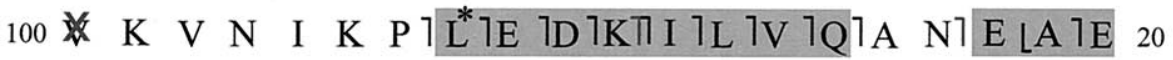

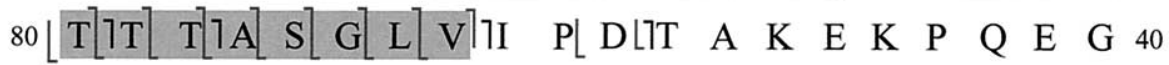

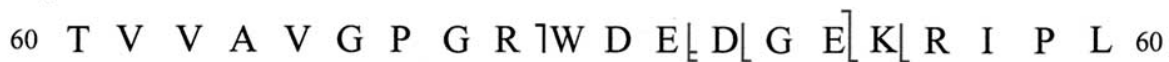

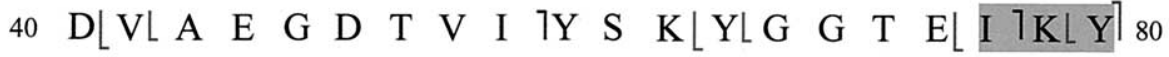

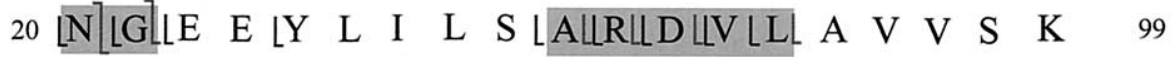
103 M R P D S TV N $1 \mathrm{~S}$ A G I TD I A A V TY 1A 7V 1A 20

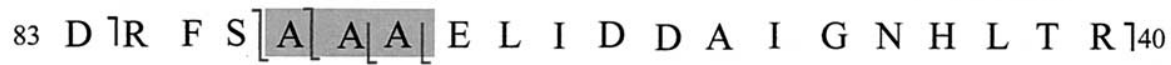

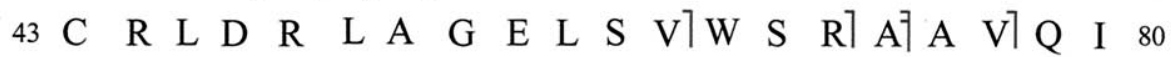
23 AL F A L R A G LA LN R YLA E LA D LL C LA A A 100 3 R I G

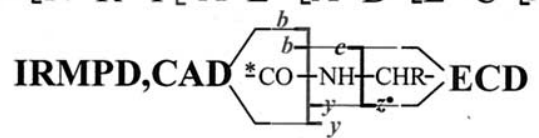

103

Figure 6. Sequence assignments from MS/MS spectra of the Figure 5 ions to: (upper) GroES and (lower) Rv3440c.

[22, 23, 40-42]. Even after allowing a single one of the common posttranslational modifications methylation, phosphorylation, glycosylation or oxidation, only 153 matches were possible. As noted previously [15], secreted proteins apparently are subjected to signal peptide loss and multiple posttranslational modifications, severely compromising the usefulness of molecular weight values for direct identification.

\section{Characterization of the Secreted Proteins}

After the SWIFT isolation, MS/MS was applied to the molecular ions of the more abundant components. CAD (Figure 2) of the abundant $10662 \mathrm{Da} 10+$ ions in Figure
1 defined a C-terminal sequence tag, Ile/Leu-Ser-X-XMet-Gly-Phe that uniquely matches that predicted for the protein CFP-10 $\left(\mathrm{M}_{\mathrm{r}}=10793, \Delta \mathrm{M}_{\mathrm{r}}=-131\right)$ encoded by the Rv3874; this was also the dominant retrieval (score 1038) in DRA matching [39] of the CAD spectrum. ECD, cleaving 35 out of 98 bonds in a single spectrum, showed the removal of the N-terminal Met (131 Da; $\mathrm{A}^{2}-\mathrm{F}^{100}$, Figure 3). CFP-10 was first identified in the short-term culture filtrate by Berthet et al. [43], with removal of N-terminus Met shown by Edman sequencing [15]. CFP-10 is co-transcribed with the potent T-cell antigen ESAT-6 for which the function is still unknown.

For another protein, $\mathrm{M}_{\mathrm{r}}=12053.2-7$ matches the value predicted for Rv1351, $\mathrm{M}_{\mathrm{r}}=12053.3-7$ (Figure 4).

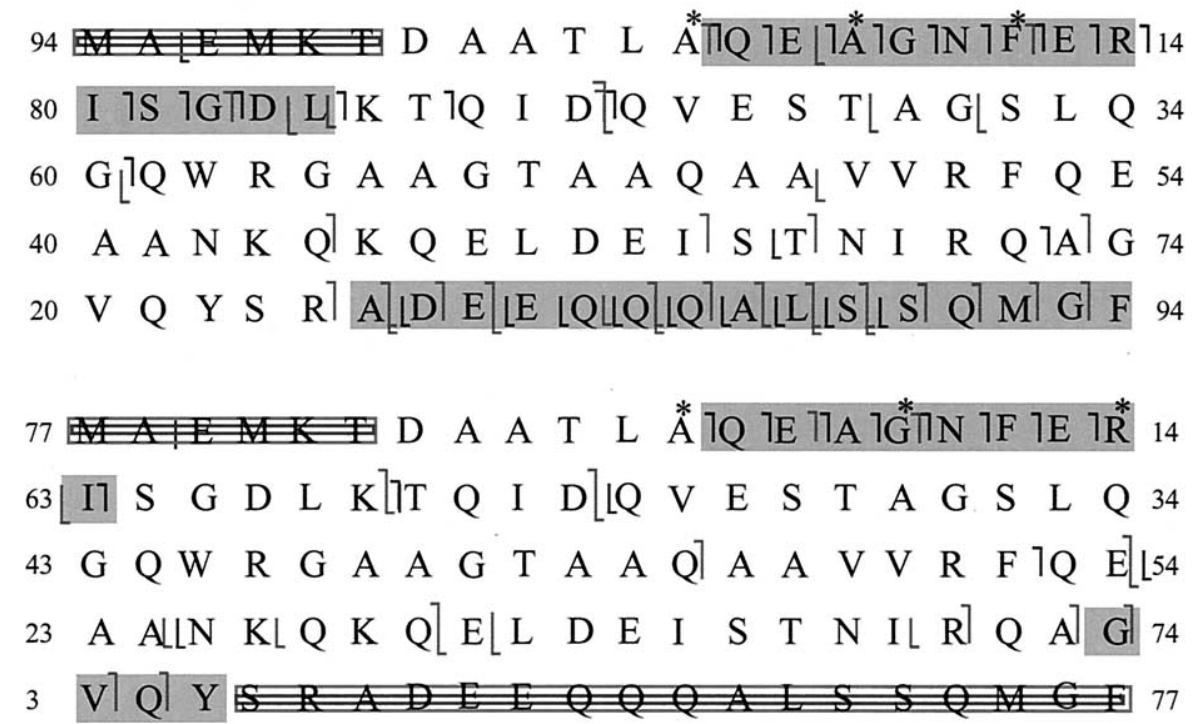

Figure 7. Sequence assignments from MS/MS spectra: upper, $\mathrm{M}_{\mathrm{r}}=10101$ ions as CFP-10, $\mathrm{D}^{7}-\mathrm{F}^{100}$; lower, $\mathrm{M}_{\mathrm{r}}=8208$ ions as CFP- $10, \mathrm{D}^{7}-\mathrm{Y}^{83}$. 
Table 1. Characterized proteins secreted from Mycobacterium tuberculosis

\begin{tabular}{|c|c|c|c|c|c|}
\hline Expt. $\mathrm{M}_{\mathrm{r}}$ & $\mathrm{M}_{\mathrm{r}}$ match & Sequence Tag & Protein, $\mathrm{M}_{\mathrm{r}}$ & Modification & Putative function \\
\hline $5059.7-3$ & Rv1119c, 5059.5-3 & $\mathrm{LD}<>\mathrm{K} / \mathrm{QAI} / \mathrm{LSS}$ & CFP-10, 10793.3-6 & $R^{57}-F^{100}$ & Antigen $[20,42]$ \\
\hline 7313.7-4 & none & $\mathrm{KA}<>\mathrm{AST}<>\mathrm{SP}$ & Rv2342, 9187.6-5 & Not determined & Exported protein \\
\hline $8142.7-5$ & none & HSYAPG & Rv1413, 17607.6-11 & Not determined & Pyridoxal enzyme \\
\hline 8208.4-5 & Rv1560, 8209.2-5 & GVK/OY-OH & CFP-10, 10793.3-6 & $D^{7}-Y^{83}$ & Antigen $[20,42]$ \\
\hline $8768.9-5$ & none & VQY-OH & CFP-10, 10793.3-6 & $A^{2}-Y^{83}$ & Antigen [20, 42] \\
\hline $10101.8-6$ & Rv0463, 10100.8-6 & K/QAI/LSSK/MG, F-OH & CFP-10, 10793.3-6 & $D^{7}-F^{100}$ & Antigen $[20,42]$ \\
\hline $10662.2-6$ & none & I/LSK/QSMGF & CFP-10, 10793.3-6 & N-term Met lost & Antigen $[20,42]$ \\
\hline 10671.6-6 & Rv3440c, 10671.4-6 & $\mathrm{YAV}<>\mathrm{AAA}$ & Rv3440c, $10671.4-6$ & none & Hypothetical protein \\
\hline $10672.6-6$ & Rv3440c, 10671.4-6 & TTTASG & GroES, 10771.6-6 & N-term Val lost & Chaperonin $[7,11,20,2$ \\
\hline $12053.2-7$ & Rv1351, 12053.3-7 & K/QAAGN-OH & Rv2376c, 16634.6-10 & 48aa signal lost & Surface antigen [20] \\
\hline
\end{tabular}

However, its CAD spectrum indicates the C-terminal sequence tag Lys/Gln-Ala-Ala-Gly-Asn-OH that corresponds to the protein encoded by Rv2376c of predicted $\mathrm{M}_{\mathrm{r}}=16634.6-10$. Removal of its $48 \mathrm{~N}$-terminal amino acids predicts $M_{r}=12053.2-7$. Rv2376c has previously been identified by Rosenkrands et al. as a short-term culture filtrate protein of unassigned function with this probable signal sequence removed [15].

The peak magnitudes of another isotopic cluster could be fitted to the theoretical isotopic distributions representing either $M_{r}=10671.6-6$ or 10672.6- 6 (Figure 5). The best $M_{r}$ match for the first value is Rv3440c $\left(\mathrm{M}_{\mathrm{r}}=10671.4-6\right)$, but the CAD sequence tag Thr-ThrThr-Thr-Ala-Ser-Gly uniquely matches GroES $\left(\mathrm{M}_{\mathrm{r}}=\right.$ 10772.6-6) and the DRA protein identification program [39] identifies GroES with a score of 1024 and Rv3440c with a score of 32. However, applying ECD also for further characterization, (20/98 interresidue bonds cleaved by CAD/IRMPD, 32/98 by ECD, Figure 6, upper), a total of 69 fragment ions match with the GroES sequence after the removal of its N-terminal Val.
The predicted Rv3440c sequence is now matched by 28 fragment ions with $8 / 102$ cleavages by CAD/IRMPD and $17 / 102$ by ECD (Figure 6, lower). The extracellular localization of GroES is consistent with its function as a chaperone in the Sec-dependent protein translocation pathway [4, 12].

Another $\mathrm{M}_{\mathrm{r}}$ value, 10101.8, would match that of a protein encoded by gene Rv2346c with the addition of Phe, yielding $\mathrm{M}_{\mathrm{r}}=10101.0$. However, CAD of its $8+$ ions identified the long sequence tag (K/Q)AI/LSS(K/ Q)MGF; this again matches the protein CFP-10, found to be the precursor of the $10662 \mathrm{Da}$ ions (vide supra). Further ECD and IRMPD/CAD fragmentation data indicates the loss of the first six amino acids on the N-terminus of CFP-10, D $-F^{100}$ (Figure 7, upper).

The ESI spectra also had 8208.4 Da ions that matched a protein encoded by gene Rv1560 of $\mathrm{M}_{\mathrm{r}}=8209.1$. However, ECD and CAD/IRMPD data matched uniquely again with CFP-10 by eliminating both the six amino acids on the N-terminus with 17 amino acids on the C-terminus, $D^{7}-Y^{83}$ (Figure 7, lower). Similarly, two
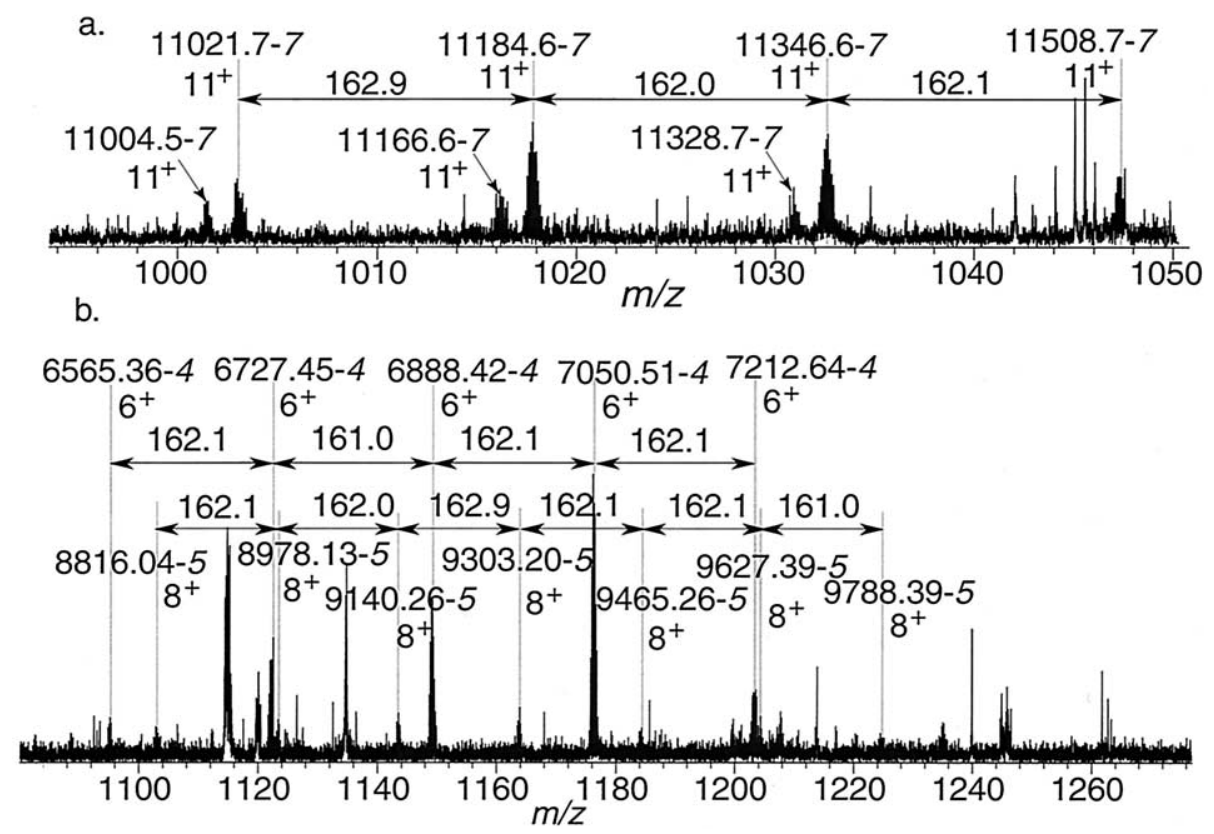

Figure 8. Partial ESI/MS spectra from: (a) one-week cell growth (Figure 1a); (b) 3-week cell growth including plus protease inhibitor cocktail (c) same without inhibitor (Figure 1b). 


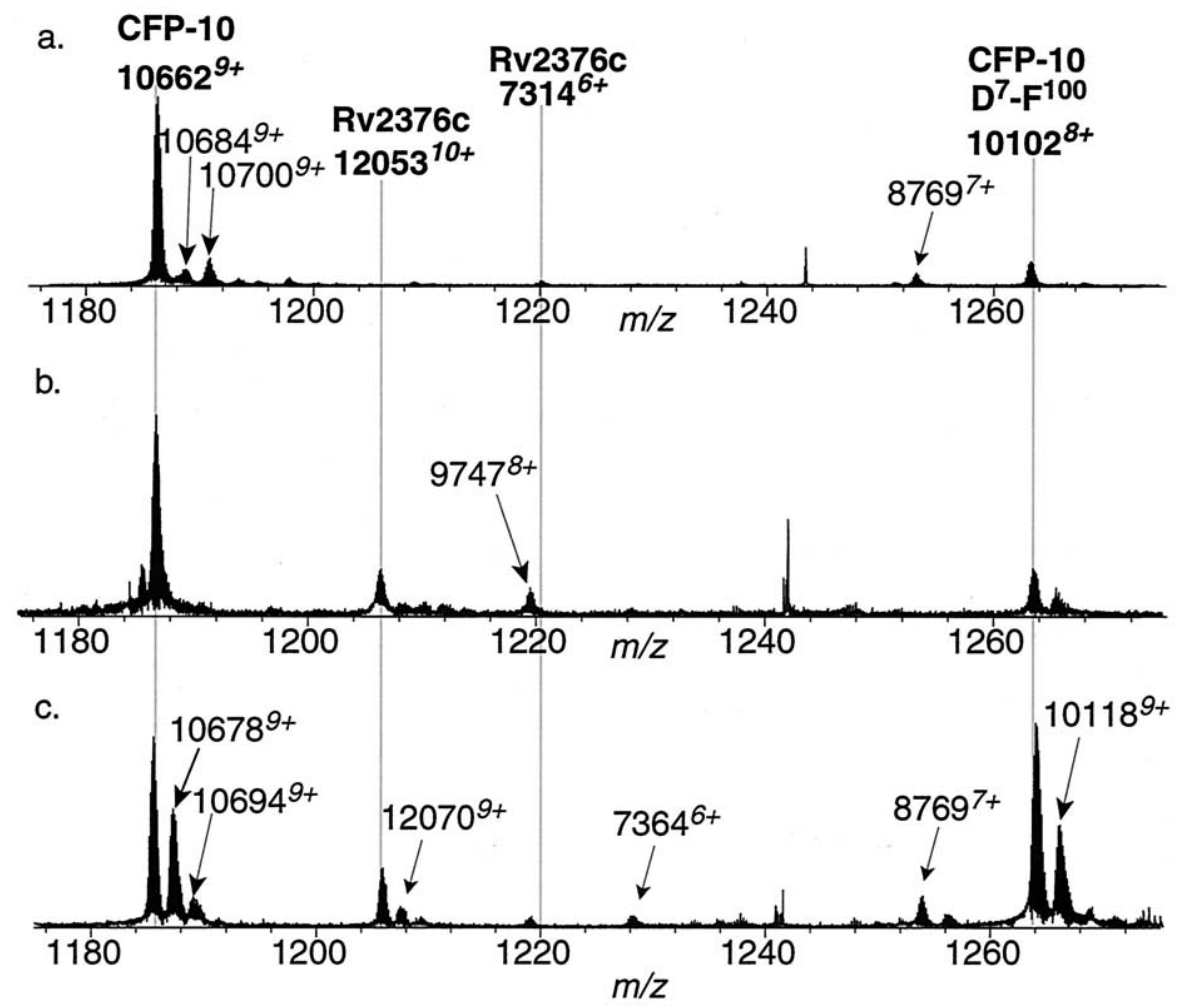

Figure 9. ESI/MS of glycoproteins eluted from a ConA column: (a) redissolved precipitates; (b) supernate.

more ESI product ions, $\mathrm{M}_{\mathrm{r}}=5059.7$ and 8768.9, were shown to be truncated CFP-10 proteins corresponding to $\mathrm{R}^{57}-\mathrm{F}^{100}$ and $\mathrm{A}^{2}-\mathrm{Y}^{83}$.

The mass values $\mathrm{M}_{\mathrm{r}}=7313.7$ and 8142.7 did not correspond to any proteins predicted in the Tuberculist database by simple molecular weight search. However, the separated sequence tags $\mathrm{KA}<>$ AST $<>$ SP and the tag HSYAPG match uniquely with proteins encoded by genes Rv2342 and Rv1413, with $\mathrm{M}_{\mathrm{r}}=9187.6$ and 17607, respectively. Their further characterization was not pursued.

\section{Secretary Modifications}

M. tuberculosis has a unique cell wall consisting of three major structures: the cytoplasmic membrane, the cell wall core that contains peptidoglycan covalently linked to a highly branched heteropolysaccharide, and an outer lipid layer composed of a wide range of complex free lipids and forms a pseudo-bilayer with the mycolic acids, characteristics of the cell walls of both Grampositive and Gram-negative bacteria [4]. M. tuberculosis secreted proteins show typical signal sequences, but these are not present in CFP-10 [44]. Hence, it is unlikely that its $\mathrm{N}$-terminus is cleaved $\left(\mathrm{D}^{7}-\mathrm{Y}^{100}, \mathrm{R}^{57}-\mathrm{F}^{100}\right.$, Table 1$)$ during Sec-dependent translocation. Instead, these and the $D^{7}-Y^{83}$ and $A^{2}-Y^{83}$ products are likely to be formed by secreted proteases. During longer cell growth period (Figure 8, a-c), or without protease inhibitor cocktail (Figure $8, \mathrm{~b}$ and $\mathrm{c}$ ) the abundance of the $\mathrm{D}^{7}-\mathrm{Y}^{100} \mathrm{CFP}-10$ protein increased several fold. Oxidation $(+16,+32 \mathrm{Da})$ is also greatly enhanced by the protease (Figure 8c).
However, the protease inhibitor cocktail does not reduce the formation of the products of $\mathrm{M}_{\mathrm{r}}=10662$, 12053, and 7314, consistent with an N-terminal Met misassignment for $\mathrm{M}_{\mathrm{r}}=10662$ and signal peptide loss for the last two.

In summary, ten proteins have been identified directly from the secreted protein mixture by sequence tag search. Three are previously identified secreted proteins. Eight proteins have been characterized, one with loss of signal sequence, two with loss of N-terminal Met and Val, and four with proteolytic degradation (Table 1).

\section{Glycoprotein Complexity}

Although protein glycosylation in eubacteria is relatively rare [20], here this was not the case. Glycoproteins were isolated on a ConA column and the eluate frozen; thawing produced a precipitate and a supernate. The ESI spectrum of the redissolved precipitate showed two glycoprotein sets, one corresponding to $\mathrm{M}_{\mathrm{r}}$

Table 2. Number of hexose attachments of glycoproteins in the Figure 9 spectra

\begin{tabular}{ll}
\hline $\mathrm{M}_{\mathrm{r}}$ & \multicolumn{1}{c}{ Attachments } \\
\hline \hline $2089.1-1$ & 0,1 \\
$6565.4-4$ & $0,1,2,3,4$ \\
$7380.7-4$ & 0,1 \\
$8816.0-5$ & $0,1,2,3,4,5,6,7$ \\
$11021.7-6$ & $0,1,2,3$ \\
$12062.7-7$ & $0,1,2$ \\
\hline
\end{tabular}




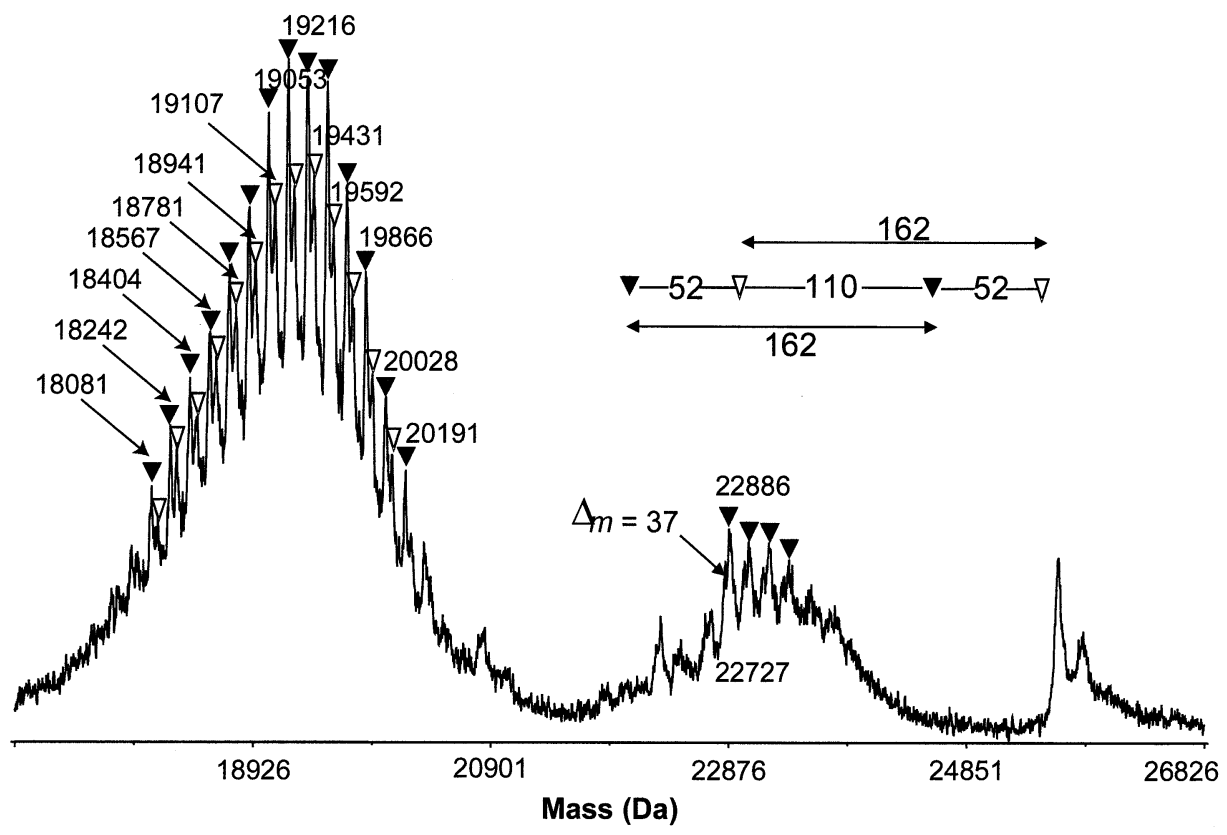

Figure 10. MALDI spectrum of glycoprotein fraction isolated using two ConA columns.

$=11021.7-7$ with 3 hexose $(+162 \mathrm{Da})$ attachments and possible loss of $\mathrm{H}_{2} \mathrm{O}(-18 \mathrm{Da})$ (Figure 9a). The spectrum of the supernate indicates four glycoprotein sets (Table $2)$, with two shown in Figure 9b. Note that some hexosamine attachments (+161 Da) are possible within experimental error. The glycosylation complexity possible for higher molecular proteins is illustrated by the MALDI spectrum (Figure 10) of the fraction eluted after two ConA columns treatment of the concentrated culture medium.

\section{Conclusion}

As a comparison to the 2-D PAGE separation of 620 resolvable spots, ESI/FTMS of different preparations of the secreted proteins from $M$. tuberculosis gave accurate molecular weight values for 689 components. However, few values matched those predicted by the DNA sequence, and no specific single modification increases the matching appreciably. Characterization (Table 1) by MS/MS techniques, for which ECD provided the most valuable results, found only one with the predicted $M_{r}$ value, and its isotopic peaks overlapped with those of another component of $\Delta \mathrm{M}_{\mathrm{r}}=1$. This failure of molecular weight matching was due to the unusual degree of protein modification that accompanies its secretion. Although, MS/MS characterization was only pursued for ten proteins, these data provide details on extensive proteolysis and oxidation, while molecular ion spectra show extensive glycosylation. Protein characterization in some biological systems can be unexpectedly challenging, making conventional techniques surely beneficial with complementary data from the top down approach with ECD.

\section{Acknowledgments}

The authors are grateful to Neil Kelleher for providing the DRA program, Jimmy Ytterberg and Klaas Jan van Wijk for the MALDI experiments, and Cynthia Kinsland, Jun Xi, David Horn, and Huili Zhai for helpful discussions. This work was supported by the National Institutes of Health, grants GM16609 to FWM and DK44083 to TPB.

\section{References}

1. Bloom, B. R.; Murray, C. J. L. Tuberculosis: Commentary on a Reemergent Killer. Science 1992, 257, 1055-1064.

2. Andersen, A. B.; Brennan, P. J. Proteins and Antigens of Mycobacterium Tuberculosis. In Tuberculosis: Pathogenesis, Protection and Control; Bloom, B. R., Ed.; American Society for Microbiology: Washington, DC, 1994; p. 307.

3. Dye, C.; Scheele, S.; Pathania, V.; Ravigilone, M. C. Global Burden of Tuberculosis. J. Am. Med. Assoc. 1999, 282, 677-686.

4. Braunstein, M.; Belisle, J. T. Genetics of Protein Secretion. In Molecular Genetics of Mycobacteria; Hatfull, G. F.; Jacobs, W. R. J., Eds.; ASM Press: Washington, DC, 2000; p. 203.

5. Brock, I.; Munk, M. E.; Kok-Jensen, A.; Andersen, P. Performance of Whole Blood IFN-gamma Test for Tuberculosis Diagnosis Based on PPD or the Specific Antigens ESAT-6 and CFP-10. Int. J. Tuberc. Lung Dis. 2001, 5, 462-467.

6. Mustafa, A. S.; Amoudy, H. A.; Wiker, H. G.; Abal, A. T.; Ravn, P.; Oftung, F.; Andersen, P. Comparison of Antigenspecific T-cell Responses Tuberculosis Patients Using Complex or Single Antigens of Mycobacterium tuberculosis. Scand. J. Immunol. 1998, 48, 535-543.

7. Siddiqui, S. M.; Orme, I. M.; Saxena, R. K. Efficacy of Culture Filtrate Protein Preparations from Indian Isolates of Mycobacterium tuberculosis to Activate T cells Derived from Healthy Donors. Int. J. Tuberc. Lung Dis. 2000, 4, 980-987.

8. Horwitz, M. A.; Lee, B.-W. E.; Dillon, B. J.; Harth, G. Protective Immunity against Tuberculosis Induced by Vaccination with Major Extracellular Proteins of Mycobacterium tuberculosis. Proc. Natl. Acad. Sci. U. S. A. 1995, 92, 1530-1534.

9. Harth, G.; Lee, B. Y.; Wang, J.; Clemens, D. L.; Horwitz, M. A. Novel Insights into the Genetics, Biochemistry, and Immnocytochemistry of the $30 \mathrm{kDa}$ Major Extracellular Protein of Mycobacterium tuberculosis. Infect. Immun. 1996, 64, 3038-3047.

10. Harth, G.; Lee, B.-W. E.; Horwitz, M. A. High Level Heterogenous Expression and Secretion in Rapidly Growing Nonpathogenic Mycobacterium tuberculosis Extracellular Proteins 
Considered to be Leading Vaccines and Drug Targets. Infect. Immun. 1997, 65, 2321-2328.

11. Nagai, S.; Wiker, H. G.; Harboe, M.; Kinomoto, M. Isolation and Partial Characterization of Major Protein Antigens in the Culture Fluid of Mycobacterium tuberculosis. Infect. Immun. 1991, 59, 372-382.

12. Sonnenberg, M. G.; Belisle, J. T. Definition of Mycobacterium tuberculosis Culture Filtrate Proteins by Two-dimensional Polyacrylamide Gel Electrophoresis, N-terminal Amino Acid Sequencing, and Electrospray Mass Spectrometry. Infect. Immun. 1997, 65, 4515-4524.

13. Cole, S. T.; Brosch, R.; Parkhill, J.; Garnier, T.; , et al. et al. Deciphering the Biology of Mycobacterium tuberculosis from the Complete Genome Sequence. Nature 1998, 393, 537-544.

14. Mollenkopf, H.-J.; Jungblut, P. R.; Raupach, B.; Mattow, J.; Lamer, S.; Zinmy-Arndt, U.; Schaible, U. E.; Kaufmann, S. H. E. A Dynamic Two-dimensional Polyacrylamide Gel Electrophoresis Database. The Mycobacterial Proteome via Internet. Electrophoresis 1999, 20, 2172-2180.

15. Rosenkrands, I.; Weldingh, K.; Jacobsen, S.; Hansen, C. V.; Florio, W.; Gianetri, I.; Andersen, P. Mapping and Identification of Mycobacterium tuberculosis Proteins by Two-Dimensional Gel Electrophoresis, Microsequencing and Immunodetection. Electrophoresis 2000, 21, 935-948.

16. Aebersold, R.; Goodlett, D. R. Mass Spectrometry in Proteomics. Chem. Rev. 2001, 101, 269-295.

17. Berger, S. J.; Lee, S.-W.; Anderson, G. A.; Paša-Tolič, L.; Tolič, N.; Shen, Y.; Zhao, R.; Smith, R. D. High-Throughput Global Peptide Proteomic Analysis by Combining Stable Isotope Amino Acid Labeling and Data-Dependent Multiplexed-MS/ MS. Anal. Chem. 2002, 74, 4994-5000.

18. Rosenkrands, I.; King, A.; Weldingh, K.; Moniatte, M.; Moertz, E.; Andersen, P. Towards the Proteome of Mycobacterium tuberculosis. Electrophoresis 2001, 21, 3740-3756.

19. Dobos, K. M.; Khoo, K.-H.; Swiderek, K. M.; Brennan, P. J.; Belisle, J. T. Definition of the Full Extent of Glycosylation of the 45-kilodalton Gycoprotein of Mycobacterium tuberculosis. J. Bacteriol. 1996, 178, 2498-2506.

20. Herrmann, J. L.; 'Gaora, P. O.; Gallagher, A.; Thole, J. E. R.; Young, D. B. Bacterial Glycoproetins: a Link between Glycosylation and Proteolytic Cleavage of a $19 \mathrm{kDa}$ Antigen from Mycobacterium tuberculosis. EMBO J. 1996, 15, 3547-3554.

21. Herrmann, J. L.; Delahay, R.; Gallagher, A.; Robertson, B.; Young, D. B. Analysis of Post-translational Modification of Mycobacterial Proteins Using a Cassette Expression System. FEBS Letters 2000, 473, 358-362.

22. Kelleher, N. L.; Lin, H. Y.; Valaskovic, G. A.; Aaserud, D. J.; Fridriksson, E. K.; McLafferty, F. W. Top Down versus Bottom Up Protein Characterization by Tandem High-Resolution Mass Spectrometry. J. Am. Chem. Soc. 1999, 121, 806-812.

23. Ge, Y.; Lawhorn, B. G.; ElNaggar, M.; Strauss, E.; Park, J.-H.; Begley, T. P.; McLafferty, F. W. Top Down Characterization of Larger Proteins (45 kDa) by Electron Capture Dissociation Mass Spectrometry. J. Am. Chem. Soc. 2002, 124, 672-678.

24. Zubarev, R. A.; Kelleher, N. L.; McLafferty, F. W. Electron Capture Dissociation of Multiply Charged Protein Cations. A Nonergodic Process. J. Am. Chem. Soc. 1998, 120, 3265-3266.

25. Zubarev, R. A.; Horn, D. M.; Fridriksson, E. K.; Kelleher, N. L.; Kruger, N. A.; Lewis, M. A.; Carpenter, B. K.; McLafferty, F. W. Electron Capture Dissociation for Structural Characterization of Multiply Charged Protein Cations. Anal. Chem. 2000, 72, 563-573.

26. Horn, D. M.; Ge, Y.; McLafferty, F. W. Activated Ion Electron Capture Dissociation for Mass Spectral Sequencing for Larger (42 kDa) Proteins. Anal. Chem. 2000, 72, 4778-4784.

27. Kelleher, N. L.; Zubarev, R. A.; Bush, K.; Furie, B.; Furie, B. C.; McLafferty, F. W.; Walsh, C. T. Localization of Labile Posttrans- lational Modifications by Electron Capture Dissociation: The Case of $\gamma$-Carboxyglutamic Acid. Anal. Chem. 1999, 71, 4250-4253.

28. Stensballe, A.; Jensen, O. N.; Olsen, J. V.; Haselmann, K. F.; Zubarev, R. A. Electron Capture Dissociation of Singly and Multiply Phosphorylated Peptides. Rapid Commun. Mass Spectrom. 2000, 14, 1793-1800.

29. Shi, S. D. H.; Hemling, M. E.; Carr, S. A.; Horn, D. M.; Lindh, I.; McLafferty, F. W. Phosphopeptide/phosphoprotein Mapping by Electron Capture Dissociation Mass Spectrometry. Anal. Chem. 2001, 73, 19-22.

30. Mirgorodskaya, E.; Roepstorff, P.; Zubarev, R. A. Localization of O-glycosylation Sites in Peptides by Electron Capture Dissociation in a Fourier Transform Mass Spectrometer. Anal. Chem. 1999, 71, 4431-4436.

31. Raynaud, C.; Etienne, G.; Peyron, P.; Laneelle, M. A.; Daffe, M. Extracellular Enzyme Activities Potentially Involved in the Pathogenicity of Mycobacterium tuberculosis. Microbiology 1998, 144, 577-587.

32. Marshall, A. G.; Wang, T. C. L.; Ricca, T. L. Tailored Excitation for Fourier Transform Ion Cyclotron Mass Spectrometry. J. Am. Chem. Soc. 1985, 107, 7893-7897.

33. Gauthier, J. W.; Trautman, T. R.; Jacobson, D. B. Sustained Off-resonance Irradiation for Collision-activated Dissociation Involving Fourier Transform Mass Spectrometry. Collisionactivated Dissociation Technique that Emulates Infrared Multiphoton Dissociation. Anal. Chim. Acta 1991, 246, 211-225.

34. Senko, M. W.; Speir, J. P.; McLafferty, F. W. Collisional Activation of Large Multiply Charged Ions Using Fourier Transform Mass Spectrometry. Anal. Chem. 1994, 66, 2801-2808.

35. Little, D. P.; Speir, J. P.; Senko, M. W.; O'Connor, P. B.; McLafferty, F. W. Infrared Multiphoton Dissociation of Large Multiply Charged Ions for Biomolecule Sequencing. Anal. Chem. 1994, 66, 2809-2815.

36. Horn, D. M.; Zubarev, R. A.; McLafferty, F. W. Automated Reduction and Interpretation of High Resolution Electrospray Mass Spectra of Large Molecules. J. Am. Soc. Mass. Spectrom. 2000, 11, 320-332.

37. http://genilist.pasteur.fr/Tuberculist/.

38. http://www.proteometrics.com/gsc_paws.html.

39. Meng, F.; Cargile, B. J.; Miller, L. M.; Forbes, A. J.; Johnson, J. R.; Kelleher, N. L. Informatics and Multiplexing of Intact Protein Identification in Bacteria and the Archaea. Nat. Biotechnol. 2001, 19, 952-957.

40. Kelleher, N. L.; Costello, C. A.; Begley, T. P.; McLafferty, F. W. Thiaminase I (42 kDa) Heterogeneity, Sequence Refinement, and Active Site Location from High-resolution Tandem Mass Spectrometry. J. Am. Soc. Mass Spectrom. 1995, 6, 981-984.

41. Kelleher, N. L.; Taylor, S. V.; Grannis, D.; Kinsland, C.; Chiu, H.-J.; Begley, T. P.; McLafferty, F. W. Efficient Sequence Analysis of the Six Gene Products $(7-74 \mathrm{kDa})$ from the Escherichia coli Thiamin Biosynthetic Operon by Tandem Highresolution Mass Spectrometry. Protein Sci. 1998, 7, 1796-1801.

42. Bruce, J. E.; Anderson, G. A.; Brands, M. D.; Pasa-Tolic, L.; Smith, R. D. Obtaining More Accurate Fourier Transform Ion Cyclotron Resonance Mass Measurements without Internal Standards using Multiply Charged Ions. J. Am. Soc. Mass Spectrom. 2000, 11, 416-421.

43. Berthet, F.-X.; Rasmussen, P. B.; Rosenkrands, I.; Andersen, P.; Gicquel, B. A Mycobacterium tuberculosis Operon Encoding ESAT-6 and a Novel Low-Molecular-mass Culture Filtrate Protein (CFP-10). Microbiology 1998, 144, 3195-3203.

44. Saleh, M. T.; Fillon, M.; Brennan, P. J.; Belisle, J. T. Identification of Putative Exported/Secreted Proteins in Prokaryotic Proteomes. Gene 2001, 269, 195-204. 